\title{
Mensagem Do Presidente da ABPoL
}

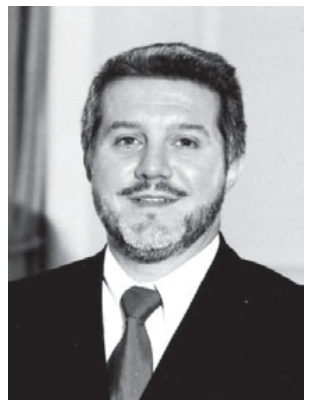

A primavera de 2003 chega para renovar o ciclo natural das estações e emoldurar o clima de eleições que envolvem os sócios e demais colaboradores e parceiros da ABPol. A eleição por voto direto de parte dos membros do Conselho em Agosto foi o passo primeiro e essencial para o avanço do processo eletivo que em Outubro resultará na eleição e composição da Diretoria da ABPol para a próxima gestão. $\mathrm{O}$ ato de eleger Conselheiros e Diretores não significa apenas o cumprimento burocrático de obrigações estatutárias mas e, principalmente, o exercício do direito e da oportunidade de renovação dos quadros dirigentes da Associação, com critérios justos e transparentes que somente o regime democrático pode garantir. A renovação tem o poder de perenizar e dinamizar as organizações ao longo do tempo. Quando Novembro chegar e a Diretoria for empossada no encerramento das atividades do 7ํㅡㄹ CBPol, em Belo Horizonte, a ABPol estará com boa parte do seu comando renovada e pronta para encarar os desafios do biênio 2004/2005.

Domingos Jafelice 